\title{
La Campana-Peñuelas Biosphere Reserve in Central Chile: threats and challenges in a peri-urban transition zone
}

\author{
Alejandro Salazar, Andrés Moreira-Muñoz \& Camilo del Río
}

Keywords: regional planning, sustainability science, ecosystem services, priority conservation sites, environmental threats

\section{Abstract}

UNESCO biosphere reserves are territories especially suited as laboratories for sustainability. They form a network of more than 600 units worldwide, intended to be key sites for harmonization of the nature-culture interface in the wide diversity of ecosystems existing on Earth. This mission is especially challenging in territories with high levels of land transformation and urbanization. The La Campana-Peñuelas Biosphere Reserve (BR) is one of these units: located in one of the world's conservation priority ecosystems, the Central Chilean Mediterranean ecoregion, it is at the same time one of the globally highly threatened spaces since the biota in this territory coexist with the most densely populated Chilean regions. This report deals with the main threats and land-use changes currently happening in the transition zone of La Campana-Peñuelas BR, which pose several challenges for the unit as an effective model of sustainability on a regional scale.
Profile

Protected area

La Campana-Peñuelas

BR

\section{Mountain range}

\section{Andes}

Country

\section{Chile}

\section{Introduction}

UNESCO biosphere reserves (BRs) can be considered laboratories for sustainability (Bridgewater 2002; Hadley 2011; Moreira-Muñoz \& Borsdorf 2014). This is explicitly recognized in the second main aim of the Seville Strategy for BRs: "utilize biosphere reserves as models of land management and of approaches to sustainable development' (UNESCO 1996). The idea is to generate such conditions that BRs become drivers of sustainable regional development. This requires implementing well-designed strategies, in areas with multiple stakeholders (public and private) on a medium to long-term time scale, since implementation of sustainability conditions is extremely complex and depends on social, political and natural conditions (Batisse 2003; German MAB National Committee 2005; Marchant \& Borsdorf 2013). This is especially relevant for ecoregions with high levels of biotic richness, highly fragile due to their location in the vicinity of urban or peri-urban areas. La Campana-Peñuelas BR is one such unit: located in one of the most relevant regions for biodiversity conservation on the planet, the Central Chilean Mediterranean ecoregion (Moreira-Muñoz 2014), it finds itself at the same time between the two most populated regions of Chile, the Metropolitan and Valparaíso regions. Together these regions are home to almost 7 million people, nearly half of Chile's population. The outer transition zone of the BR includes several human settlements and touches on the periurban zone of the Valparaíso-Quilpué agglomeration (Figure 1). In contrast, the BR cores - La Campana National Park, Lago Peñuelas National Reserve and Cerro el Roble Natural Sanctuary - are the last areas for the protection of regional ecosystems diversity and local endemic species (Luebert et al. 2009; Hauenstein et al. 2009), see Figure 1.

Recognizing that Central Chile possesses great species richness and endemism, which are under imminent risk of extinction due to ecosystem fragmentation (Pliscoff \& Fuentes-Castillo 2011; Moreira-Muñoz 2014), regional strategies for biodiversity conservation have proposed a number of priority conservation sites for the protection of biological diversity that coincide within the zonation of the BR (Moreira-Muñoz \& Salazar 2014) (Figure 1). These sites usually come in conflict with the urban sprawl and the agriculture expansion capabilities (e. g. Nori et al. 2013), and La Campana-Peñuelas BR is no exception. Due to their precarious administration and management, these sanctuaries and priority sites are exposed to all sorts of threats, including large-scale forest fires (Figure 2).

The current threats to biodiversity and ecosystem services gives the La Campana-Peñuelas BR great importance on a global scale (as UNESCO reserve), national scale (including national parks, reserves, sanctuaries and priority sites) and regional scale, and poses major challenges for management and governance, taking into account the various levels of decision-making and actions that occur in such a relevant territory.

\section{The peri-urban space and the transition zone in La-Campana-Peñuelas BR}

The peri-urban spaces may be the dominant settlements' areas of the $21^{\text {st }}$ century and constitute one of the highest spatial planning challenges (Ravetz et al. 2013). The peri-urban ring, also called the urban fringe (Scott et al. 2013), is a low-density settlement zone, usually with large open spaces, situated between 

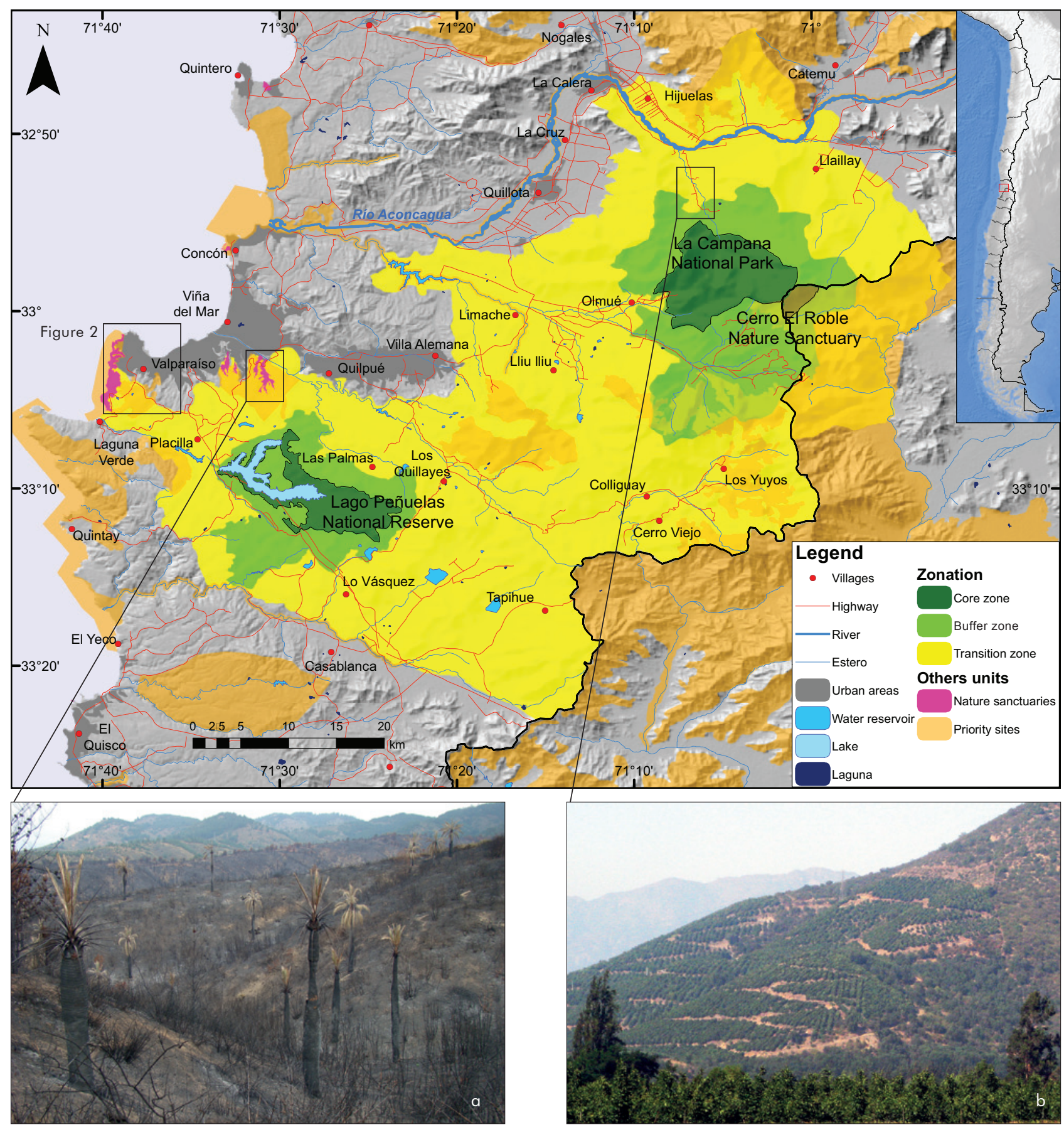

Figure 1 - Conflicts in the zone where peri-urban space meets the transition zone of the BR. BR zonation including biodiversity conservation priority sites and natural sanctuaries outside the BR cores, cartography by Francisco González; a) the Palmar El Salto Natural Sanctuary is affected almost every year by forest fire, in this case of February 2012. (C) Patricio Novoa; b) aspects of the advancing agricultural frontier in the Ocoa area. (C) A. Moreira-Muñoz.

a suburban area and an urban periphery, the whole surrounded in turn by a rural hinterland (Ravetz et al. 2013). This empirically based model mirrors the BR model in a way: a natural semi-pristine core zone, surrounded by a buffer zone and a transition zone where human activities gradually dominate.

Both centre-periphery models have a contact zone that can be seen as a conflict zone or alternatively as a zone of opportunities for sustainability. Particularly in the BRs facing strong urban pressure, conflicts and governance issues have a significant impact on their actual possibility of becoming models of sustainability. In this regard, it is important to recognize, in the case of Chile, the significant challenges and lack of coordination present in the governance of urban spaces, enhanced by the complex rural-urban interface, in which various stakeholders, social and political aspirations, land use, environmental services and associated interests overlap, and where obvious conflicts arise at various levels as a product of their competition (Salazar 2008). 


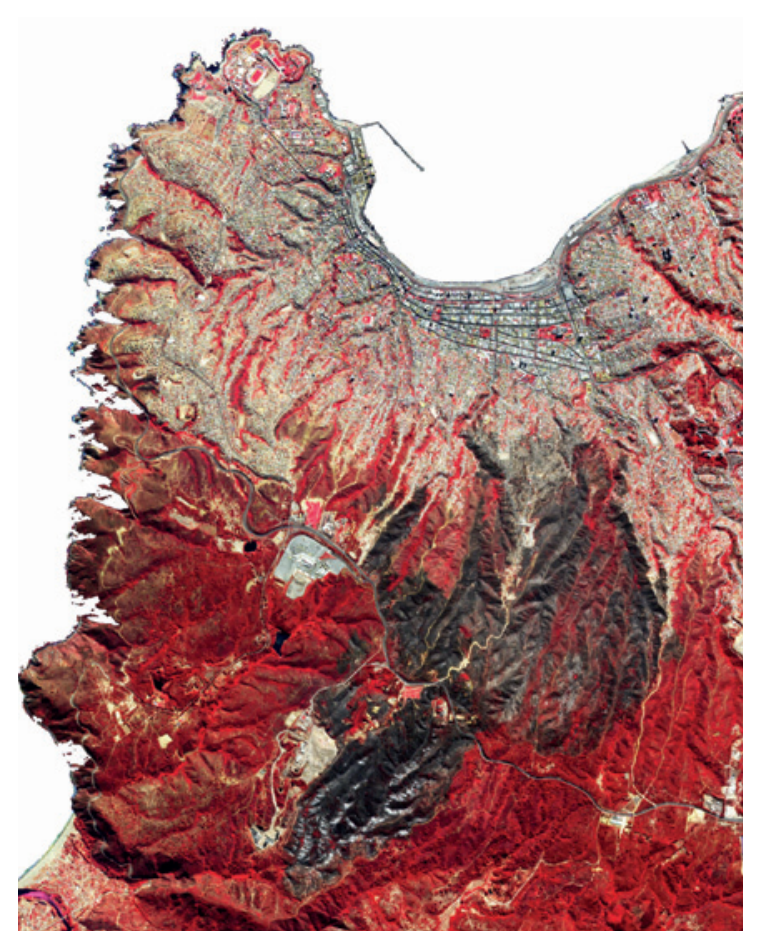

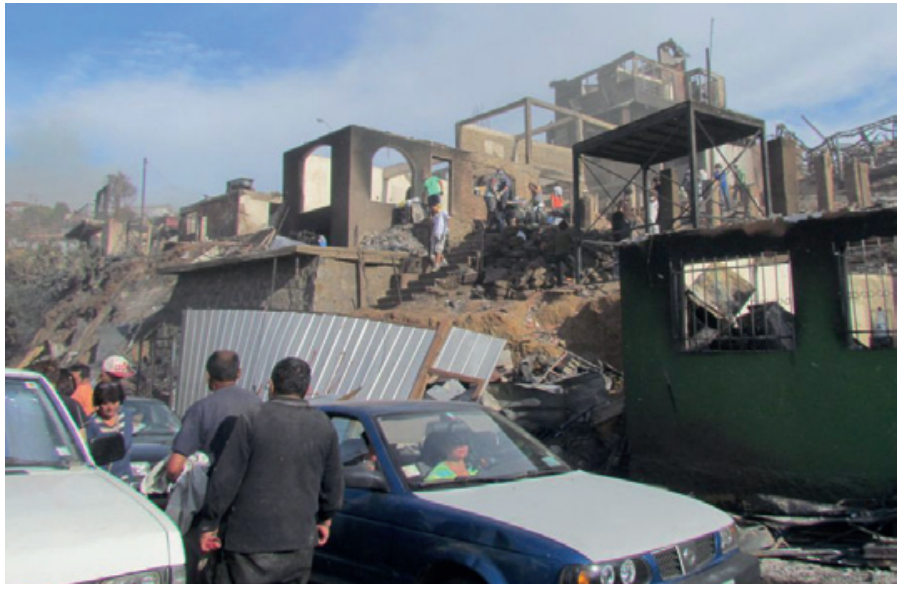

Figure 2 - False colour composite (combination of the near-infrared, red and green bands) of the RapidEye Constellation (5 $\mathrm{m}$ pixel size) of Valparaiso shows the area affected by the big fire of 12 April 2014 in the La Pólvora sector in the billsides of Valparaiso) aspects of the fire that affected around 1000 ba of the BR contact zone, including forest plantations and around 3000 houses of informal settlement. Source: Satellite image by BlackBridge (bttp:/ / www.blackbridge.com/). (C) Paula Pérez.
Understanding and recognizing the emergent ruralurban dynamics (demographic, social, residential and productive) in the context of a bioregion beyond the limits of the urban core (Brunckhorst 2000) is crucial for long-term regional environmental planning, especially nowadays in the context of processes of urban sprawl related to a new mobility paradigm. This results in a unique displacement system, in terms of providing daily services to the surrounding territories of significant environmental value, where environmental amenities play an important role, inhabited by an increasingly mobile urban-rural population (Borsdorf \& Hidalgo 2009). Thus the density of rural-urban people's spatial activities, which include work, consumption, recreation and socializing, may account for the diversity of relations with space and with other inhabitants. This is in addition to the complexity shaping the lifestyles in each territory, related also to the transformation of traditional activities like agriculture and tourism (Balmford et al. 2009; Winchell et al. 2010; Ravecz 2013). These changes will certainly affect the biodiversity as well as the availability of water resources for agriculture, industry and human settlements in relation to the regional ecosystem services provision (Potschin \& Haines-Young 2011; Rojas et al. 2013; Reckien et al. 2014).

Below we assess current and potential development projects affecting the $\mathrm{BR}$, taking into account the dynamics of the processes occurring at the contact zone between the peri-urban ring and the BR's transition zone. Figure 3 shows the increase in urban area in recent decades, as well as the agricultural expansion in the same period, by means of satellite images. The urban sprawl between 1985 and 2011 in the western part of the transition zone near Lago Peñue- las National Reserve has increased the urban space by around 440 ha for the Curauma area and by 2230 ha in the Quilpué area (Figure 3a). Looking at the agricultural boundaries a clear trend emerges: for example, in the northern part of the transition zone, agricultural use has been expanded by 2905 ha in the same period (Figure 3b), similarly in the north-eastern sample window, with an increase of 3100 ha in agricultural land use (Figure 3c). Also note the high variability of the water resource in the outline of Lake Peñuelas, which provides drinking water to the main city of Valparaíso.

\section{Transforming the peri-urban ring as an op- portunity for sustainability}

The cities and populated settlements are part of a system surrounded by a rural hinterland; the protected areas form a system, surrounded by an urban and peri-urban hinterland. It is an issue of perspective. Like settlements, protected areas cannot be treated as islands within the territory anymore and must come to form a network of reserves, interconnected by biological corridors that serve as structural and functional connectors (Sepúlveda et al. 1997; Crouzeilles et al. 2013). This general principle implies shifting the focus to consider the function of the rings within the BR. Rather than thinking of the buffer zone as a contention zone, it could be understood as an area of opportunities for ecological restoration. For its part, the transition zone could be seen as an expansion zone of ecosystem services. This model differs conceptually from the traditional protection model in that it considers centrifugal forces of expanding the reserve core's objectives outwards rather than centripetal forces pro- 

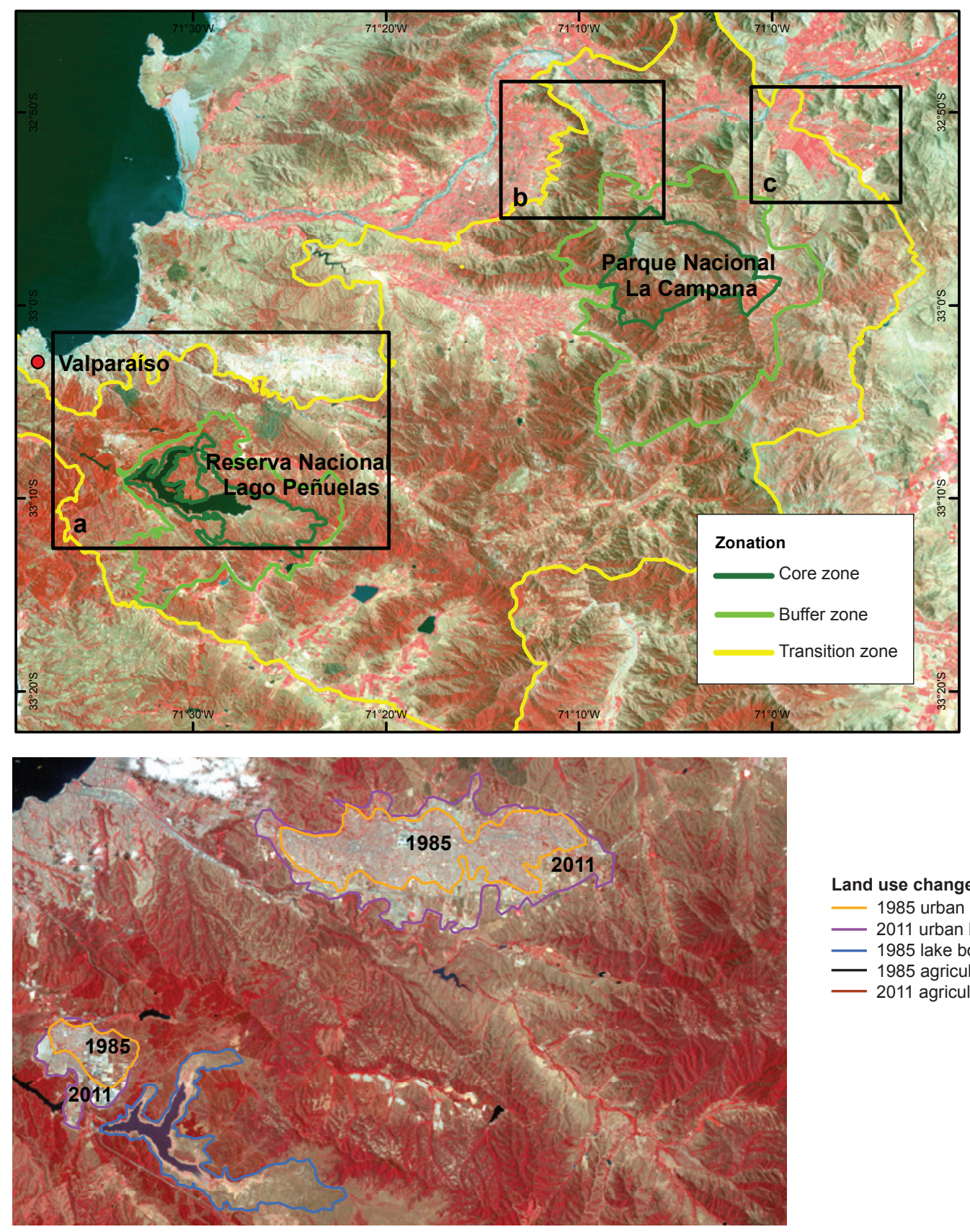

Land use change

1985 urban boundaries

2011 urban boundaries

1985 lake boundaries

1985 agriculture boundaries

— 2011 agriculture boundaries
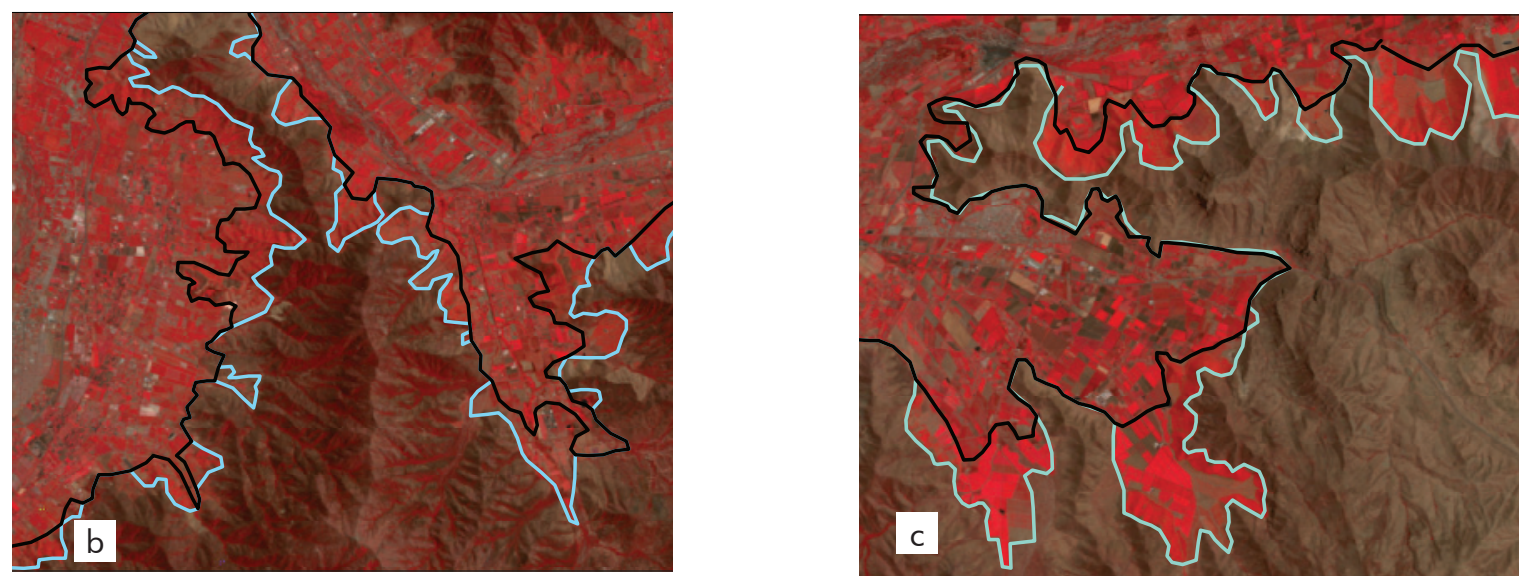

Figure 3 - Land-use change in La Campana-Peñuelas BR, based on a temporal analysis of Landsat-5 TM false colour composites from 1985 (25 January) and 2011 (1 January ): a) changes in urban boundaries at Quilpué-Villa Alemana and Curauma; b) and c) expansion of the agricultural boundaries in the same period. In a) note also the huge change in water surface of Lake Peñuelas, related to the high interannual variations. Cartography: Camilo del Rio 
tecting the core against the threats of human action (Moreira-Muñoz \& Salazar 2014).

Communities embedded in these areas are fundamental to any collective action, strategies or agreements in the search for sustainability in the transition zone (Salazar 2010). In this sense, BRs have to be engaged in community-based conservation (Batisse 2003; Kothari et al. 2013; Ruiz-Mallen \& Corbera 2013) through adaptive governance. The most successful systems of adaptive governance are emergent and self-organized; they connect individuals, networks, organizations, agencies and institutions at multiple levels of organization with ecosystem dynamics (Gunderson \& Light 2006; Folke et al. 2011). The zonation of La Campana-Peñuelas BR was the result of a participatory mapping process (Meynard 2009). Nowadays there are more tools to support the co-construction of places (Collinge \& Gibney 2010; Etienne et al. 2011; McCall \& Dunn 2012). Conceptual-practical advances include the explicit cartography of ecosystem services (Nahuelhual et al. 2013), assessment and improvement of spatial resilience (Cumming 2011), and enhancement of eco-civic governance (Brunckhorst \& Reeve 2006). In biologically relevant peri-urban areas like the La Campana-Peñuelas BR, all efforts need to be harnessed towards environmental regional planning, recognizing that any improvement of the quality of life of the human populations must be tied in with maintaining the ecosystem's richness, quality and resilience.

\section{Acknowledgments}

This report includes results obtained by Fondecyt projects \# 1100999 (2010) and \#1120448 (2012), and is part of the Puente \#10 (2013) project from Vicerrectoría de Investigación at the Pontificia Universidad Católica de Chile. Work was also supported by the CEDEUS Program Conicyt/Fondap/15110020.

\section{References}

Balmford, A., J. Beresford, J. Green, R. Naidoo, M. Walpole \& A. Manica 2009. A Global Perspective on Trends in Nature-Based Tourism. PLoS Biology 7 (6): $\mathrm{n}^{\circ} \mathrm{e} 1000144$.

Batisse, M. 2003. Developing and focusing the Biosphere Reserve concept. In: Thakur, B. (ed.), Perspectives in resource management in developing countries: 160-177. New Delhi.

Bridgewater, P.B. 2002. Biosphere reserves: special places for people and nature. Environmental Science \& Policy 5 (1): 9-12.

Borsdorf, A. \& R. Hidalgo. 2009. Searching for fresh air, tranquility and rural culture in the mountains: A new lifestyle for Chileans? Die Erde 140 (3): 275-292.

Brunckhorst, D.J. 2000. Bioregional Planning: Resource Management Beyond the New Millennium. New York.

Brunckhorst, D.J. \& I. Reeve 2006. A Geography of Place: principles and application for defining 'eco-civ- ic' resource governance regions. Australian Geographer 37 (2): 147-166.

Collinge, C. \& J. Gibney 2010. Place-making and the limitations of spatial leadership: reflections on the Oresund. Policy Studies 31 (4): 475-489.

Crouzeilles, R., M.L. Lorini \& C.E. Viveiros Grelle 2013. The importance of using sustainable use protected areas for functional connectivity. Biological Conservation 159: 450-457.

Cumming, G.S. (2011). Spatial Resilience in Social-Ecological Systems. Dordrecht.

Etienne, M., D.R. Du Toit \& S. Pollard. 2011. ARDI: a co-construction method for participatory modeling in natural resources management. Ecology and Society 16 (1): $\mathrm{n}^{\circ} 44$.

Folke, C., A. Jansson, J. Rockström, P. Olsson, S.R. Carpenter, F.S. Chapin III, A.S. Crépin, G. Daily, K. Danell, J. Ebbesson, T. Elmqvist et al. 2011. Reconnecting to the Biosphere. AMBIO 40: 719-738.

German MAB National Committee (ed.) 2005. Full of Life: UNESCO Biosphere Reserves - Model Regions for Sustainable Development. Berlin \& Heidelberg.

Hadley, M. 2011. Cuarenta años de laboratorios del desarrollo sostenible al aire libre. Un Mundo de Ciencia 9 (4): 2-11. UNESCO, Paris.

Hauenstein, E., A. Muñoz-Pedreros, J. Yánez, P. Sánchez, P. Möller, B. Guiñez \& C. Gil 2009. Flora y vegetación de la Reserva Nacional Lago Peñuelas, Reserva de la Biosfera, Región de Valparaíso, Chile. Bosque 30 (3): 159-179.

Kothari, A., P. Camill \& J. Brown 2013. Conservation as if People Also Mattered: Policy and Practice of Community-based Conservation. Conservation \& Society 11 (1): 1-15.

Luebert, F., M. Muñoz-Schick \& A. Moreira-Muñoz 2009. Vegetación y Flora de La Campana. In: Elórtegui, S. \& A. Moreira-Muñoz (eds.), Parque Nacional La Campana: origen de una Reserva de la Biosfera en Chile Central ( $2^{\text {nd }}$ edition): 36-69. Fondo de Las Américas, Taller La Era, Santiago.

Marchant, C. \& A. Borsdorf 2013. Protected areas in Northern Colombia - on track to sustainable development? eco.mont 5 (2): 5-14.

McCall, M.K. \& C.E. Dunn 2012. Geo-information tools for participatory spatial planning: Fulfilling the criteria for 'good' governance? Geoforum 43 (1): 81-94.

Meynard, F. 2009. ¿Qué es una Reserva de Biosfera? In: Elórtegui, S. \& A. Moreira-Muñoz (eds.), Parque Nacional La Campana: origen de una Reserva de la Biosfera en Chile Central (2nd edition): 162-167. Fondo de Las Américas, Taller La Era, Santiago.

Moreira-Muñoz, A. 2014. Endemism in Mainland Regions: Central Chile Ecoregion. In: Hobohm, C. (ed.), Endemism in Vascular Plants. Series Plant and Vegetation 9: 221-233. Dordrecht.

Moreira-Muñoz, A. \& A. Borsdorf (eds.) 2014. Reservas de la Biosfera de Chile: Laboratorios para la Sustentabilidad. Academia de Ciencias de Austria, Pontificia 
Universidad Católica de Chile, Instituto de Geografía, serie Geolibros n 17 , Santiago.

Moreira-Muñoz, A. \& A. Salazar 2014. Reserva de la Biosfera La Campana-Peñuelas: micro-región modelo para la planificación del desarrollo regional sustentable. In: Moreira-Muñoz, A. \& A. Borsdorf (eds.), Reservas de la Biosfera de Chile: Laboratorios para la Sustentabilidad. Academia de Ciencias de Austria, Pontificia Universidad Católica de Chile, Instituto de Geografía, serie Geolibros 17: 104-121. Santiago.

Nahuelhual, L., A. Carmona, P. Lozada, A. Jaramillo \& M. Aguayo (2013). Mapping recreation and ecotourism as a cultural ecosystem service: An application at the local level in Southern Chile. Applied Geography 40: 71-82.

Nori, J., J.N. Lescano, P. Illoldi-Rangel, N. Frutos, M.R. Cabrera \& G.C. Leynaud 2013. The conflict between agricultural expansion and priority conservation areas: Making the right decisions before it is too late. Biological Conservation 159: 507-513.

Potschin, M.B. \& R.H. Haines-Young 2011. Ecosystem services: Exploring a geographical perspective. Progress in Physical Geography 35 (5): 575-594.

Ravetz, J., C. Fertner \& T.A. Sick Nielsen 2013. The Dynamics of Peri-Urbanization. In: Nilsson, K., S. Pauleit, S. Bell, C. Aalbers \& T.A. Sick Nielsen (eds.), Peri-urban futures: Scenarios and models for land use change in Europe: 13-44. Heidelberg.

Reckien, D., J. Flacke, R.J. Dawson, O. Heidrich, M. Olazabal, A. Foley, J.J.-P. Hamann, H. Orru, M Salvia, $S$ de Gregorio Hurtado, D Geneletti \& F Pietrapertosa 2014. Climate change response in Europe: what's the reality? Analysis of adaptation and mitigation plans from 200 urban areas in 11 countries. Climatic Change 122 (1-2): 331-340.

Rojas, C., J. Pino, C. Basnou \& M. Vivanco 2013. Assessing land-use and -cover changes in relation to geographic factors and urban planning in the metropolitan area of Concepción (Chile). Implications for biodiversity conservation. Applied Geography 39: 93-103

Ruiz-Mallen, I. \& E. Corbera 2013. Community-Based Conservation and Traditional Ecological Knowledge: Implications for Social-Ecological Resilience. Ecology and Society 18 (4): 12.

Salazar, A. 2008. Los espacios rurales periurbanos en la futura gestión metropolitana: Santiago de Chile. In: Yáñez, G., A. Orellana, O. Figueroa \& F. Arenas (eds.), Ciudad, poder y gobernanza. EURE Libros y Geolibros $\mathrm{n}^{\circ}$. Instituto de Estudios Urbano y Territoriales, Instituto de Geografía UC, LOM Ediciones: 201-215. Santiago.

Salazar, A. 2010. Transformaciones socioterritoriales en la periferia metropolitana: la ciudad periurbana, estrategias locales y gobernanza en Santiago de Chile. Scripta Nova. Revista Electrónica de Geografia y Ciencias Sociales XIV: 331 [http://www. ub.edu/geocrit/sn/sn-331/sn-331-47.htm]

Scott A.J., C. Carter, M.R. Reed, P. Larkham, D. Adams, N. Morton, R. Waters \& D. Collier, et al. 2013. Disintegrated development at the rural-urban fringe: Re-connecting spatial planning theory and practice. Progress in Planning 83: 1-52.

Sepúlveda, C., A. Moreira-Muñoz \& P. Villarroel 1997. Conservación biológica fuera de las áreas silvestres protegidas. Ambiente \& Desarrollo 13 (2): 48-58.

UNESCO 1996. Biosphere Reserves. The Seville Strategy and the Statutory Framework of the World Network. Paris.

Winchell, D.G., D. Ramsey, R. Koster, G.M. Robinson (eds.) 2010. Geographical Perspectives on Sustainable Rural Change. Rural Development Institute, Brandon University, Manitoba, Canada.

\section{Authors}

\section{Alejandro Salazar ${ }^{1,2}$}

Studied geography at the Pontificia Universidad Católica de Chile (UC) and holds a PhD in Social Sciences from the Institut National Agronomique ParisGrignon (INA PG). Currently professor at the Institute of Geography (UC). His research interests are peri-urban areas and land-use changes.

Email:asalazab@uc.cl

\section{Andrés Moreira-Muñoz ${ }^{3}$}

Studied geography at the Pontificia Universidad Católica de Chile (UC) and holds a PhD in Natural Sciences, University of Erlangen-Nürnberg. Currently professor at the Institute of Geography (UC). His research interests are conservation biogeography and sustainability science. Email: asmoreir@uc.cl

\section{Camilo del Río}

Studied geography at the Pontificia Universidad Católica de Chile (UC) and holds a Master's degree in Geography and Geomatics. Currently professor at the Institute of Geography (UC). His research topics are remote sensing and its applications in spatiotemporal land-use change analysis. Email: cdelriol@uc.cl

1 Instituto de Geografía, Pontificia Universidad Católica de Chile, Av. Vicuña Mackenna 4860, Macul, Santiago

${ }^{2}$ CEDEUS (Centro de Desarrollo Urbano Sustentable) UC-UDEC

${ }^{3}$ Instituto de Geografía, Pontificia Universidad Católica de Valparaíso, Avenida Brasil 2241, Valparaíso, Chile 